\title{
Michigan faces disposal ban
}

\section{Boston}

EVERY week, Michigan hospitals, research laboratories and nuclear plants churn out tonnes of radioactive waste, just like those in the rest of the country. But unlike the other states, Michigan now has nowhere to dispose of this waste. And unless state officials reach a compromise with neighbouring states, some Michigan facilities may have to stop using radioactive materials, or risk drowning in their own hazardous debris.

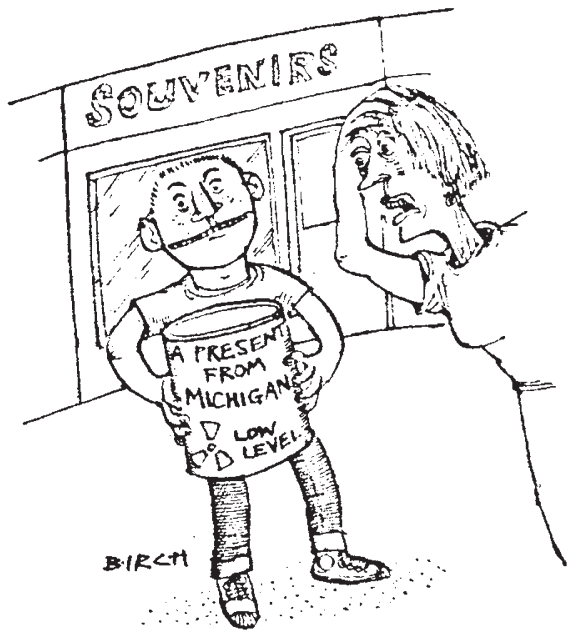

Last month, the three states with lowlevel radioactive waste landfills banned all waste from Michigan until the state makes some progress with setting up its own repository. The ban was announced simultaneously by officials in Nevada, Washington and South Carolina, with immediate effect.

The move underlines the United States' quandary over low-level waste disposal: existing repositories are due to be closed and public opposition means that most states are behind schedule in opening new sites.

Some states, including California and Nebraska, have made progress in setting up new sites, but no state wants to be the first for fear that it will then become the

\section{COMPUTER INDUSTRY}

\section{US companies join European initiative}

\section{London}

The Joint European Submicron Silicon Initiative (JESSI), a \$5,000 million collaborative semiconductor research programme set up in 1989 to help the struggling European computer industry to compete with the United States and Japan, is opening its doors to US companies. American Semiconductor Manufacturing Technology (SEMATECH), a consortium of 14 US companies, and IBM Europe, are both to join JESSI projects. resting place of all low-level radioactive waste in the United States. Indeed, the incoming governor of Nebraska has threatened to halt progress until other states catch up.

The action against Michigan's waste illustrates the resolve of states with repositories not to accept the nation's low-level waste indefinitely. As Bill Miller, the governor of Nevada said, "this action should demonstrate to all concerned that Nevadans will not tolerate any attempts to delay closure" of the Nevada repository beyond the end of 1992 .

Under the US low-level radioactive waste laws, the three states with repositories are authorized to impose sanctions against states that are not making progress towards building new low-level waste facilities. All facilities must be ready by 1993 .

Michigan, designated as the repository state for a group of seven midwestern states, has just been forced to drop the last site under consideration for a low-level waste repository because of concern about nearby wetlands. It must now begin again, prospecting some 78 remaining possible areas. "We are back to the drawing board", said one Michigan official.

Michigan is the largest but not the first state to lose its rights to dump low-level radioactive wastes. Vermont, New Hampshire and Rhode Island as well as Puerto Rico and the District of Columbia have previously lost access for failure to make provisions for the wastes they generate, and other states, including Connecticut, Maine, Massachusetts, New Jersey and New York have been warned of similar action. Virtually all states are held up by battles over sites.

The federal government is trying to take a lead with several national proposals. Earlier this year, the Nuclear Regulatory Commission (NRC) announced that it would exempt "some or all regulatory controls [from] certain practices involving small quantities of radioactive material". The NRC claims that excluding low levels of radioactivity as 'below regulatory concern' (BRC) would allow it to focus its efforts on regulating activities that pose the most serious health threats.

Critics believe the move is designed to slash the cost of decommissioning nuclear power plants by allowing radioactive waste that falls 'below regulatory concern' to be disposed of in the same way as any other waste.

Although the nuclear industry has adopted the BRC framework, there are fears that a fall in the volume of lowlevel radioactive waste would lead to even greater disposal problems by creating an economic disincentive to build any new repositories.

Seth Shulman

\section{More money for applied research}

\section{São Paulo}

BRAZIL intends to more than double the amount it spends on research and development by 1994, the end of President Fernando Collor de Mello's term, Secretary of Science and Technology José Goldemberg said last week. At present, just 0.7 per cent of the country's gross national product is spent on research and development (R\&D), but Goldemberg said more is needed to make Brazilian industry competitive in the international market. Private Brazilian companies currently spend US\$200 million a year on R\&D, and receive another US\$60 million from federal agencies. Goldemberg wants to increase the federal contribution to US\$1,430 million in 1994 from these agencies an increase of 2,283 per cent - and to encourage industry to spend an additional US\$474 million of its own money. Resources

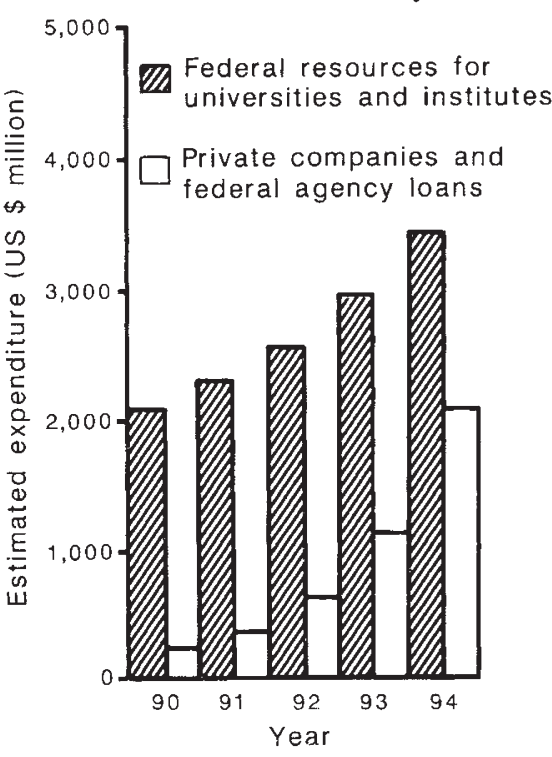

Brazil's R\&D expenditure plans

for universities and research institutes would grow from US $\$ 2,070$ million this year to about US\$3,462 million in 1994 under his plan.

The president of the Brazilian Society for the Progress of Science, Ennio Candotti, is sceptical. "Before thinking of 1993 or 1994, we must see how scientific institutions will survive the penury they face in 1990 and 1991", he says.

- DESPITE the objections of their armed forces, Argentina and Brazil agreed last week that neither would build nuclear weapons. The agreement, signed by Argentinian President Carlos Saul Menem and his Brazilian counterpart, Fernando Collor de Mello, is intended to convey that both are "responsible" nations in nuclear matters, said Brazil's Secretary of Science and Technology, José Goldemberg.

Ricardo Bonalume 